\title{
Improved Teacher Scientific Publication Competency Based On Sustainable Professional Development at Tanbisaw
}

\author{
Riry Sriningsih $^{* 1}$, Helma ${ }^{1}$, Dewi Murni ${ }^{1}$ \\ ${ }^{1}$ Jurusan Matematika Fakultas Matematika dan Ilmu Pengetahuan Alam Universitas Negeri Padang \\ Jln. Prof. Dr. Hamka, Air Tawar Padang \\ * Correspondence: srirysriningsih@ @ahoo.com; Telp: +62 852-7283-2235
}

Diterima 25 Oktober 2018, Disetujui 26 Oktober 2018, Dipublikasikan 30 November 2018

\begin{abstract}
Based on observations, the results of questionnaires and discussions with elementary school teachers in Tanbisaw, Kubung Subdistrict, Solok Regency, found two main factors causing the majority of teachers to be heavy and difficult to publish their writings, namely: 1) Motivation and 2) Substance. Most teachers state that procedures for making scientific works and publications have criteria that are too difficult to fulfill or follow. The teacher has not found any material that is worth writing. The teacher stated that they did not have the time to do research and look for reading sources to write. The purpose of this activity is to motivate and improve the competence of teachers in producing scientific publications in carrying out their duties through Sustainable Professional Development. Specifically, the aim is to: 1) direct teachers to produce research ideas, 2) guide teachers in compiling scientific publications, and 3) inform and direct teachers to publish works at national seminars and scientific journals. The activity was held at SDN 02 Tanjung Bingkung, with participants being elementary school teachers consisting of 8 elementary schools, the methods used were: lecture methods, guided training, discussion and direct practice in writing and making scientific papers to be published.
\end{abstract}

Keywords - scientific work, publication, Continuing Professional Development

\section{Pendahuluan}

Guru yang profesional tidak hanya melakukan fungsi terkait dengan kompetensi pedagogis seperti merencanakan, melakukan, menilai dan mengadministrasi pembelajaran, tetapi juga fungsi yang terkait dengan kompetensi kepribadian, sosial, dan keprofesionalan. Fungsi tersebut antara lain ditandai dengan peningkatan diri melalui penulisan karya ilmiah.

Karya ilmiah merupakan karya tulis yang isinya berusaha memaparkan suatu pembahasan secara ilmiah yang dilakukan oleh seorang penulis atau peneliti [1]. Materi yang dituangkan dalam tulisan ilmiah berupa gagasan-gagasan ilmiah, baik berupa hasil kajian ilmiah maupun hasil-hasil penelitian yang disajikan dalam karya tulis ilmiah. Gagasangagasan itu merupakan gambaran perkembangan ilmu pengetahuan yang terekam dalam tulisan ilmiah. Secara lebih singkat, karya tulis ilmiah merupakan karangan yang menyajikan fakta umum yang dapat dibuktikan kebenarannya secara ilmiah dan ditulis dengan metodologi yang benar [2].

Karakteristik keilmiahan sebuah karya terdapat pada isi, penyajian, dan bahasa yang digunakan. Isi karya ilmiah tentu bersifat keilmuan, yakni rasional, objektif, tidak memihak, dan berbicara apa adanya. Isi sebuah karya ilmiah harus fokus dan bersifat spesifik pada sebuah bidang keilmuan secara mendalam. Kedalaman karya tentu sangat disesuaikan dengan kemampuan sang ilmuwan. Bahasa yang digunakan juga harus bersifat baku, disesuaikan dengan sistem ejaan yang berlaku di Indonesia. Bahasa ilmiah tidak menggunakan bahasa pergaulan, tetapi harus menggunakan bahasa ilmu pengetahuan, mengandung hal-hal yang teknis sesuai dengan bidang keilmuannya [1].

Fungsi karya ilmiah adalah sebagai sarana komunikasi akademik dalam sebuah bidang kajian keilmuan. Disamping itu fungsi dan 
manfaat menulis karya ilmiah yang bersifat pragmatis adalah mengembangkan karir dan kepangkatan guru sebagai tenaga profesional [1].

Keputusan Menteri Negara

Pendayagunaan Aparatur Negara nomor 84/1993 tentang Jabatan Fungsional Guru dan Angka Kreditnya, serta Keputusan bersama Menteri Pendidikan dan kebudayaan dan Kepala BAKN Nomor 0433/P/1993, nomor 25 tahun 1993 tentang Petunjuk Pelaksanaan Jabatan Fungsional Guru dan Angka Kreditnya, pada prinsipnya bertujuan untuk membina karier kepangkatan dan profesionalisme guru.

Penulisan karya ilmiah tidak saja diperlukan untuk memperoleh angka kredit kenaikan jabatan atau untuk keperluan sertifikasi melalui portofolio, tetapi juga diperlukan untuk peningkatan kualitas pengelolaan kelas, layanan kepada peserta didik, dan peningkatan profesionalisme. Karya tulis ilmiah tersebut dapat berupa karya tulis ilmiah hasil penelitian, pengkajian, survei dan evaluasi, karya tulis/ makalah berupa tinjauan atau ulasan ilmiah gagasan sendiri, tulisan ilmiah populer, prasaran berupa tinjauan wawasan atau ulasan ilmiah yang disampaikan pada pertemuan ilmiah, buku pelajaran atau modul, diktat pelajaran, menerjermahkan karya ilmiah, skripsi, tesis, buku, paper, artikel, dan berbagai produk lain [3].

Untuk kenaikan pangkat seorang guru diwajibkan untuk menyusun karya ilmiah sesuai dengan kepangkatannya. Namun demikian masih ada sebagian guru yang belum berupaya untuk mengembangkan profesinya, bahkan belum tahu apa itu pengembangan profesi berkelanjutan [4].

Permenpan nomor 84/1993 juga mengisyaratkan pentingnya kegiatan Pengembangan Keprofesian Berkelanjutan (PKB). Pengembangan Keprofesian Berkelanjutan (PKB) dilaksanakan dalam upaya mewujudkan guru yang profesional, bermatabat dan sejahtera; sehingga guru dapat berpartisifasi aktif untuk membentuk insan Indonesia yang bertakwa kepada Tuhan YME, unggul dalam ilmu pengetahuan dan teknologi, memiliki jiwa estetis, etis, berbudi pekerti luhur, dan berkepribadian [5].

PKB terdiri dari serangkaian aktivitas reflektif yang dirancang untuk meningkatkan kemampuan, pengetahuan, pemahaman, dan keterampilan seseorang. PKB mencakup gagasan bahwa individu selalu bertujuan untuk meningkatkan keterampilan dan pengetahuan profesional mereka di luar apa yang mereka dapatkan dalam pelatihan dasar yang mereka terima ketika pertama kali melakukan pekerjaan tersebut [6].

PKB dilakukan dengan komitmen secara holistik terhadap struktur keterampilan dan kompetensi pribadi atau bagian penting dari kompetensi profesional. Dalam hal ini adalah suatu komitmen untuk menjadi profesional dengan memenuhi standar kompetensi profesinya, selalu memperbaharuimya, dan secara berkelanjutan untuk terus berkembang. Untuk itu, PKB harus mendorong dan mendukung perubahan khususnya di dalam praktek-praktek dan pengembangan karir guru. PKB mencakup tiga hal; yakni pengembangan diri, publikasi ilmiah, dan karya inovatif [7].

Kegiatan pengembangan keprofesian yang perlu dilakukan guru adalah melakukan publikasi ilmiah. Publikasi Ilmiah adalah karya tulis ilmiah yang telah dipublikasikan kepada Masyarakat [8]. Dalam hal ini publikasi ilmiah dapat dimaknai sebagai upaya untuk menyebarluaskan suatu karya pemikiran seseorang atau sekelompok orang, dalam bentuk laporan penelitian, makalah, buku atau artikel. Kegiatan melaksanakan publikasi ilmiah yang dilakukan guru pada dasarnya merupakan wujud dari profesionalisme guru [5].

Publikasi ilmiah mencakup 3 kelompok kegiatan yaitu: presentasi pada forum ilmiah, publikasi ilmiah hasil penelitian atau gagasan inovatif pada bidang pendidikan formal, dan publikasi buku teks pelajaran, buku pengayaan dan/atau pedoman guru [9].

Kenyataan di lapangan menunjukkan bahwa sedikit sekali guru yang berani mempublikasikan karya ilmiahnya. Hal ini dapat dilihat dari jumlah guru yang mencapai golongan IVb. Disamping itu, dapat juga dilihat dari tulisan yang muncul pada jurnal atau terbitan lainnya. Sebagian besar guru masih merasa berat dan sulit untuk mempublikasikan karya tulis mereka.

Berdasarkan observasi, hasil angket dan diskusi dengan guru SD KKG Gugus V Tanbisaw 
Kecamatan Kubung Kabupaten Solok ditemukan dua faktor utama penyebab sebagian besar guru masih merasa berat dan sulit untuk menulis dan mempublikasikan hasil karyanya, yaitu motivasi dan substansi. Beberapa alasan penyebab rendahnya motivasi menulis karya ilmiah ini dan mempublikasikannya adalah ketakutan atau kecemasan menulis terkait dengan prosedur dan kriteria tulisan yang dapat diterima dan dihargai sebagai karya ilmiah. Sebagian terbesar mereka menyatakan bahwa prosedur pembuatan karya ilmiah dan publikasi, kriterianya terlalu sulit untuk mereka penuhi atau ikuti. Disamping itu, mereka belum menemukan adanya bahan yang layak untuk ditulis. Mereka menyatakan belum mempunyai waktu untuk melakukan penelitian dan mencari sumber-sumber bacaan untuk ditulis.

\section{Solusi}

Solusi yang dapat dilakukan adalah meningkatkan kompetensi guru untuk menghasilkan dan mempublikasikan karya ilmiah menurut tuntutan Pengembangan Keprofesian Berkelanjutan (PKB).

Langkah yang diberikan adalah memberikan pelatihan kepada guru, yaitu:

1. Mengarahkan guru dalam melahirkan ide-ide penelitian.

2. Membimbing guru dalam menyusun publikasi ilmiah

3. Menginformasikan dan mengarahkan guru untuk mempublikasikan hasil karya pada seminar nasional dan jurnal ilmiah.

\section{Hasil dan Diskusi}

Hasil kegiatan yang dilakukan adalah sebagai berikut:

1. Pemahaman guru terhadap penting dan perlunya menulis sebuah karya ilmah sesuai dengan tuntutan Pengembangan Keprofesian Berkelanjutan (PKB) meningkat. Hal ini terlihat dari antusias guru dalam mengikuti pelatihan. Tidak hanya itu, peningkatan juga terjadi pada pengetahuan dan wawasan guru tentang penelitian tindakan kelas
2. Guru sudah bisa melahirkan ide-ide penelitian, salah satunya ide penelitian tindakan kelas.

3. Guru sudah bisa mengembangkan ide-ide penelitiannya tersebut

4. Guru sudah bisa melakukan teknik mengumpulkan data dengan cara menetapkan jenis data kualitatif dan kuantitatif. Data kualitatif diperoleh dari catatan observasi, angket, dan wawancara triangulasi data. Data kuantitatif diperoleh dari nilai kuis dan nilai hasil belajar siswa

5. Guru sudah bisa mencari informasi dan menginterpretasi temuan

6. Guru sudah bisa mengolah data dengan menggunakan MS.Excel

7. Guru sudah bisa menganalisis dan menginterpretasikan hasil analisis data yang diperoleh serta menemukan solusi dari permasalahan yang diutarakan

8. Guru sudah bisa menulis sebuah karya ilmiah sesuai tuntutan PKB

9. Guru menghasilkan draf karya ilmiah

Kegiatan pelatihan yang sudah dilakukan ditelaah kebermaknaannya sesuai dengan tujuan kegiatan. Hal ini dilakukan dengan cara memberikan angket kepada peserta pelatihan pada pertemuan terakhir. Tujuan pemberian angket ini adalah untuk mengetahui tanggapan peserta terhadap pelaksanaan kegiatan dan hasil yang dirasakan, sekaligus memberikan saran untuk kegiatan-kegiatan pengabdian selanjutnya.

Secara umum, terdapat tiga indikator yang ditelaah, yaitu: 1) peningkatan pengetahuan dan wawasan tentang penelitian tindakan kelas, 2) manfaat pelatihan pembuatan artikel ilmiah, dan 3) tindak lanjut dari kegiatan pelatihan. Lembaran angket yang diberikan kepada peserta pelatihan menggunakan Skala Likert dengan menggunakan empat pilihan sangat setuju (SS), setuju (S), tidak setuju (TS), dan sangat tidak setuju (STS). Hasil analisis terhadap angket peserta pelatihan dapat digambarkan tanggapan peserta untuk setiap indikator.

Pada indikator pertama ada enam hal yang dituju melalui kegiatan pelatihan ini. Berdasarkan analisis data diperoleh bahwa 80\% guru menjawab setuju bahwa kegiatan pelatihan telah 
dapat meningkatkan pengetahuan dan wawasan guru tentang penelitian tindakan kelas.

Pada indikator kedua ada empat hal yang dituju melalui kegiatan pelatihan ini. Berdasarkan hasil angket yang diberikan, disimpulkan bahwa pelatihan ini memberikan manfaat bagi guru sebesar $31.67 \%$ menjawab sangat setuju dan $65 \%$ menjawab setuju.

Pada indikator ketiga ada lima hal yang dituju melalui kegiatan pelatihan ini dan disimpulkan bahwa pelatihan ini memberikan rasa optimis bagi guru untuk dapat menulis artikel ilmiah sebesar $72 \%$ yang menyatakan setuju.

Berdasarkan analisis terhadap angket yang diberikan, dengan adanya kegiatan pelatihan ini guru merasa termotivasi dan optimis untuk dapat membuat penelitian tindakan kelas dan selanjutnya penelitian tersebut dibuat beberapa artikel ilmiah yang sesuai dengan tuntutan PKB serta diterima pada jurnal nasional baik terakreditasi ataupun tidak terakreditasi.

Berdasarkan hasil angket yang diberikan kepada peserta pelatihan pada akhir pertemuan dirangkum kesan dan saran peserta dan dipaparkan sebagai berikut. Kesan yang disampaikan oleh peserta pelatihan tersebut adalah (a) kegiatan ini menambah pengetahuan dan wawasan peserta tentang penelitian tindakan kelas, (b) peserta menjadi termotivasi dalam menulis artikel ilmiah, dan (c) peserta merasa terbantu mengatasi kesulitannya selama ini dalam menulis dan mempublikasikan artikel ilmiah.

Adapun saran untuk kegiatan ini adalah (a) pelatihan yang diberikan sebaiknya dilakukan berturut-turut 6 kali pertemuan (dalam 1 minggu), (b) memberikan pelatihan kembali pada tahun 2019 tentang bagaimana cara mengirim artikel secara online dan memperbaiki artikel sesuai dengan saran reviewer.

\section{Kesimpulan}

Berdasarkan kegiatan yang sudah dilakukan dapat disimpulkan bahwa:

1. Guru sudah berani dan memiliki motivasi tinggi menulis sebuah karya ilmiah

2. Guru sudah bisa menghasilkan ide-ide dalam menulis sebuah karya ilmiah
3. Guru suda bisa mengumpulkan dan menganalisis data dari ide penelitiannya

Guru sudah bisa menulis karya ilmiah sesuai tuntutan PKB

Adapun saran berdasarkan kegiatan yang dilakukan adalah:

1. Hasil kegiatan pelatihan pengabdian kepada masyarakat ini disarankan kepada guru untuk terus menulis dan menghasilkan karya ilmiah yang bereputasi

2. Guru yang dilatih dapat membagikan ilmu yang diperolehnya selama pelatihan kepada guru lain disekolahnya ataupun sekolah lain

Guru diharapkan dapat mengembangkan ilmu yang diperolehnya selama pelatihan untuk lebih berkarya

\section{Ucapan Terima Kasih}

Terima kasih kepada semua pihak yang telah membantu dan berpartisipasi dalam kegiatan pengabdian ini, terutama kepada kepala sekolah SDN 02 Tanjung Bingkung tempat pelaksanaan kegiatan dan ketua KKG Gugus V Tanbisaw Kecamatan Kubung Kabupaten Solok.

\section{Pustaka}

[1] Supriyadi, (2013). Modul Perkuliahan Bahasa Indonesia. Modul 8, Penulisan Karya Ilmiah. Universitas Mercubuana.

[2] Ridwan Arifin, (2012). Pengertian, Jenis, dan Ciri Karya Tulis. http://chetarmembaha.blogspot.com/2012/12/peng ertian-jenis-dan-ciri-karya- tulis.html

[3] Supartinah, (2012). Penyusunan Karya Tulis Ilmiah. PGSD FIP Universitas Negeri Yogyakarta

[4] Sukanti (2014). Pengembangan Profesi Guru Secara Berkelanjutan. Universitas Negeri Yogya.http://staff.uny.ac.id/sites/default/files/peng abdian/sukanti-dra-mpd/pengembangankeprofesian-berkelanjutan.pdf

[5] Akhmad Sudrajat, (2011). Penilaian Kinerja Guru dan Pengembangan Keprofesian Berkelanjutan. http://akhmadsudrajat.wordpress.com/ 2011/11/08/ kinerja-guru-dan-pengembangankeprofesian-berkelanjutan

[6] Muhammad Faiz, (2013). Peningkatan Profesionalisme guru dan PKB (Pengembangan 
Keprofesian Berkelanjutan) untuk Guru dan Mahasiswa Calon Guru.penelitiantindakankelas.blogspot.com/2013/ 11/peningkatan-rofesionalisme-guru- melaluiPKB.html

[7] Syawal Gultom, (2012). Pedoman Pengelolaan Pengembangan Keprofesian Berkelanjutan (PKB). Kementrian Pendidikan Nasional Direktorat Jenderal Peningkatan Mutu Pendidik dan Tenaga Kependidikan.

[8] Mohammad Nuh, (2010). Lampiran Peraturan Menteri Pendidikan Nasional Nomor 35 Tahun 2010 Tentang Petunjuk Teknis Pelaksanaan Jabatan Fungsional Guru dan Angka Kreditnya. Departemen Pendidikan Nasional.

[9] Dian Mahsunah, (2012). Kebijakan Pengembangan Profesi Guru: Materi Pendidikan dan Latihan Profesi Guru. Badan Pengembangan Sumber Daya Manusia Pendidikan dan Kebudayaan dan Penjaminan Mutu Pendididikan Kementrian Pendidikan dan Kebudayaan. 